\title{
Retracted: Microfluidic Method of Pig Oocyte Quality Assessment in Relation to Different Follicular Size Based on Lab-on-Chip Technology
}

\author{
BioMed Research International \\ Received 25 November 2014; Accepted 25 November 2014 \\ Copyright (C) 2015 BioMed Research International. This is an open access article distributed under the Creative Commons \\ Attribution License, which permits unrestricted use, distribution, and reproduction in any medium, provided the original work is \\ properly cited.
}

The paper titled "Microfluidic Method of Pig Oocyte Quality Assessment in Relation to Different Follicular Size Based on Lab-on-Chip Technology" [1], published in BioMed Research International, has been retracted as it was submitted for publication without the knowledge and approval of the coauthor Jan Dziuban.

\section{References}

[1] B. Kempisty, R. Walczak, P. Antosik et al., "Microfluidic method of pig oocyte quality assessment in relation to different follicular size based on Lab-on-Chip technology," BioMed Research International, vol. 2014, Article ID 467063, 9 pages, 2014. 